PRACE GEOGRAFICZNE

zeszyt 157, 2019, 51-68

doi: 10.4467/20833113PG.19.009.10625

Instytut Geografii i Gospodarki Przestrzennej UJ

Komisja Geograficzna, Polska Akademia Umiejętności

Wydawnictwo Uniwersytetu Jagiellońskiego

\title{
ODDZIAŁYWANIE STAWÓW HODOWLANYCH NA JAKOŚĆ WODY RZEKI WĄSKIEJ
}

\author{
Roman Cieślinski, Izabela Chlost, Karol Lewowicki
}

\section{Impact of fish ponds on the quality water in the Wąska river}

Abstract: The aim of the study is to determine the influence of freshwater fish farming on the chemical status of water in the catchment of the Wąska river. The paper presents the results of physicochemical studies of water supplying and discharged from fish ponds at Klekotki. At measurement points located on the Wąska river above and below the ponds the following properties were determined: total nitrogen, total phosphorus and concentrations of dissolved ammonia, nitrates, phosphates, sulphates. The observations showed that the physicochemical state of water supplying the ponds is below good because of too high phosphate concentrations $\left(0.57 \mathrm{mg} \cdot \mathrm{dm}^{-3}\right.$ above the joints and $0.41 \mathrm{mg} \cdot \mathrm{dm}^{-3}$ below). In spite of that, it was stated that fish farming can positively affect the water purification process and improve the physical and chemical parameters of water, as evidenced by the reduction of total nitrogen concentrations by $66 \%$, ammonia by $52 \%$, sulphates by $50 \%$, nitrates by $46 \%$ and phosphate by $28 \%$, below the discharge of water from the ponds in relation to the supplying waters. In addition, it was found that the dynamics of biogen transport in the fish pond system is characterized by a clear seasonal differentiation and is associated with the size of outflow.

Keywords: fish ponds, water quality, physicochemical indicators, hydrographic conditions, pollutant load

Zarys treści: Celem pracy jest określenie wpływu hodowli ryb słodkowodnych na stan chemiczny wody zlewni Wąskiej. W pracy przedstawiono wyniki badań fizyczno-chemicznych wody zasilającej i zrzucanej ze stawów rybnych w miejscowości Klekotki. W punktach pomiarowych zlokalizowanych na rzece Wąskiej przed i poniżej stawów oznaczono: azot ogólny 
i fosfor ogólny oraz stężenie substancji rozpuszczonych - amoniak, azotany(V), fosforany(V), siarczany(VI). Przeprowadzone obserwacje dowiodły, że stan fizyczno-chemiczny wody zasilającej stawy jest poniżej dobrego z powodu m.in. zbyt wysokiego stężenia fosforanów(V) $\left(0,57 \mathrm{mg} \cdot \mathrm{dm}^{-3}\right.$ powyżej stawów i $0,41 \mathrm{mg} \cdot \mathrm{dm}^{-3}$ poniżej $)$. Pomimo to stwierdzono, że chów ryb może pozytywnie wpływać na proces oczyszczania wody i poprawę parametrów fizyczno-chemicznych wody, czego dowodem jest redukcja stężeń azotu ogólnego o 66\%, amoniaku o $52 \%$, siarczanów(VI) o $50 \%$, azotanów $(\mathrm{V})$ o $46 \%$ i fosforanów $(\mathrm{V})$ o $28 \%$, poniżej zrzutu wody ze stawów w stosunku do wód zasilających. Dodatkowo stwierdzono, że dynamika transportu biogenów w systemie stawów rybnych cechuje się wyraźnym zróżnicowaniem sezonowym i jest związana z wielkością odpływu.

Stowa kluczowe: stawy rybne, jakość wody, wskaźniki fizyczno-chemiczne, warunki hydrograficzne, ładunek zanieczyszczeń

\section{Wstęp}

Całkowita powierzchnia wód śródlądowych w Polsce to ponad 566 tys. ha, z czego około $85 \%$ tych wód wykorzystywane jest do działalności rybackiej. Produkcja ryb słodkowodnych (karpia i pstrąga) prowadzona jest głównie (w około 70\%) w stawach i basenach. Powierzchnia samych stawów rybnych w Polsce to około 70 tys. ha (Karoń 2011).

Stawy rybne bardzo często postrzegane są jako zbiorniki pełniące funkcję wyłącznie produkcyjną. Ich udziału nie można jednak sprowadzić tylko do pojedynczego przeznaczenia. Stawy hodowlane odgrywają bowiem szczególną rolę w kształtowaniu chemizmu wód i obiegu wody (retencji) w zlewni (Kosturkiewicz i in. 1993; Wojda, Zygmunt 2012), a także decydują o zanieczyszczeniu mikologicznym (Berleć i in. 2015). Według Rozporæqdzenia Rady Ministrów z dnia 9 listopada 2010 r. w sprawie przedsięwzię́ mogqcych snaczaco oddziatywać na środowisko (Dz.U. 2016 poz. 71) stawy hodowlane zaliczane są do grupy inwestycji mogących potencjalnie znacząco oddziaływać na środowisko. Chów ryb przyczynia się do powstawania rozpuszczalnych w wodzie zanieczyszczeń, które mogą doprowadzić do znacznego pogorszenia się chemizmu wód. Podstawowym źródłem zanieczyszczenia wód powierzchniowych są resztki niepobranej i niestrawionej paszy oraz substancje wydalane przez ryby (Bonisławska i in. 2017), które wpływają na rozwój mikroorganizmów (Bieniarz i in. 2003; Quant i in. 2009; Sidoruk i in. 2013). Powoduje to wzrost koncentracji zawiesiny ogólnej oraz wzrost obciążenia materią organiczną (Read, Fernandes 2003), a także wzrost zasobności wody w organiczne i nieorganiczne związki fosforu i azotu (Boyd 2003; Bonisławska i in. 2013, 2016). Jakość wód odprowadzanych z gospodarstw rybackich zależna jest nie tylko od rodzaju i sposobu chowu ryb, lecz także od jakości wód zasilających gospodarstwa rybackie, gatunku ryb, rodzaju i ilości paszy, a także czynników meteorologicznych 
i fizjograficznych (Kolasa-Jamińska 2004; Barszczewski i in. 2010). Duże znaczenie ma również wielkość zbiornika przeznaczonego do hodowli. Zdarza się jednak, że jakość wody poniżej stawów hodowlanych jest lepsza niż powyżej (Pytka i in. 2013; Kanownik, Wiśnios 2015). Według Michalczyka i in. (2017) stopień redukcji biogenów w stawach rybnych wzrasta wraz z rozmiarem obiektów wodnych i wielkością produkcji.

Podczas chowu ryb niepożądanym procesem jest m.in. eutrofizacja (Pawlik-Dobrowolski, Łempicka 2003; Bonisławska i in. 2017) oraz zmiany wielkości tlenu rozpuszczonego (Jawecki i in. 2008). Przy niewielkim zanieczyszczeniu wody doprowadzającej stawy o ekstensywnej gospodarce nie wpływają znacząco na cechy chemiczne wody powierzchniowej. W przypadku znacznego zanieczyszczenia wód doprowadzanych retencyjny charakter stawów prowadzi do ich oczyszczenia (Kolasa-Jamińska 2004).

Celem badań jest określenie wpływu hodowli ryb słodkowodnych na stan chemiczny wody rzeki Wąskiej oraz przeanalizowanie zmienności czasowej jakości wody.

\section{Miejsce badań}

Analizowane gospodarstwo rybackie znajduje się $24 \mathrm{~km}$ na wschód od Pasłęka, w miejscowości Klekotki, w dolinie rzeki Wąskiej należącej do zlewni jeziora Druzno. Stawy rybne wchodzące w skład gospodarstwa należą do grupy stawów kroczkowych, gdzie produkuje się karpia metodą ekstensywną (z żywieniem naturalnymi paszami). Wydajność z 1 ha lustra wody nie przekracza $800 \mathrm{~kg} \cdot \mathrm{ha}^{-1}$ (Gospodarstwo Rybackie Klekotki).

Rzeka Wąska bierze początek w północno-wschodniej części mezoregionu Pojezierza Iławskiego. Środkowy odcinek rzeki biegnie przez głęboką dolinę znajdującą się na Równinie Warmińskiej. W strefie ujściowej Wąska wpływa na tereny Żuław Wiślanych, uchodząc do jeziora Druzno (gdos.gov.pl). Omawiane stawy położone są we wschodniej części zlewni rzeki Wąskiej. Badany obszar o powierzchni $35 \mathrm{~km}^{2}$ zajmuje północno-wschodnią część Pojezierza Iławskiego. Jest to część zlewni rzeki Wąskiej, której profil zamykający znajduje się w punkcie 2 (ryc. 1). Wyżynno-pagórkowate ukształtowanie terenu sprzyja gwałtownym wezbraniom po obfitych opadach deszczu. W tym czasie w wodzie unoszona jest duża ilość nawozów i zawiesin pochodzących z użytków rolnych.

Wąska o długości 47,1 km i powierzchni zlewni 254,4 km² jest jednym z największych dopływów jeziora Druzno (Radtke i in. 2011). Rzekę podzielono na dwie jednolite części wód. Górny odcinek stanowi jednolitą część wód o nazwie „Wąska do Sały z Sałą", o powierzchni 186,55 km² i łącznej długość cieków 71,7 km, którą 
Tab. 1. Charakterystyka zastawek piętrzących w obiekcie stawowym Markowo-Podony Table 1. Characteristics of stagnation valves in the Markowo-Podony joint facility

\begin{tabular}{|c|c|c|c|c|c|}
\hline $\begin{array}{l}\mathrm{Nr} \\
\text { No. }\end{array}$ & $\begin{array}{l}\text { Lokalizacja/ Kilometr } \\
\text { Location / Kilometre }\end{array}$ & $\begin{array}{c}\text { Rzędna progu }[\mathrm{m}] \\
\text { Elevation threshold } \\
{[\mathrm{m}]}\end{array}$ & $\begin{array}{l}\text { Rzędna max. } \\
\text { piętrzenia [m] } \\
\text { Maximum } \\
\text { elevation level } \\
{[\mathrm{m}]}\end{array}$ & $\begin{array}{l}\text { Rzędna min. } \\
\text { piętrzenia [m] } \\
\text { Minimum } \\
\text { elevation level } \\
{[\mathrm{m}]}\end{array}$ & $\begin{array}{c}\text { Światło }[\mathrm{m}] \\
\text { Light }[\mathrm{m}]\end{array}$ \\
\hline $\begin{array}{l}\text { Zastawka } \\
\text { piętrząca Nr } 4 \\
\text { Stagnation valve } \\
\text { No. } 4\end{array}$ & $\begin{array}{l}\text { Wypływ rzeki Wąskiej } \\
\text { z j. Zimnochy } \\
-45+760 \mathrm{~km} \\
\text { Outflow of the Wąska } \\
\text { river from Zimnochy lake } \\
-45+760 \mathrm{~km}\end{array}$ & 92,40 & 93,80 & 93,26 & 1,8 \\
\hline $\begin{array}{l}\text { Zastawka } \\
\text { piętrząca Nr } 3 \\
\text { Stagnation valve } \\
\text { No. } 3\end{array}$ & $45+260 \mathrm{~km}$ & 91,10 & 92,80 & - & 2,0 \\
\hline $\begin{array}{l}\text { Zastawka } \\
\text { piętrząca Nr } 2 \\
\text { Stagnation valve } \\
\text { No. } 2\end{array}$ & $42+600 \mathrm{~km}$ & 85,69 & 88,09 & - & 2,0 \\
\hline $\begin{array}{l}\text { Zastawka } \\
\text { piętrząca Nr } 1 \\
\text { Stagnation valve } \\
\text { No. } 1\end{array}$ & $\begin{array}{l}600 \mathrm{~m} \text { powyżej stopnia } \\
\text { wodnego w Klekotkach } \\
-41+660 \mathrm{~km} \\
600 \mathrm{~m} \text { above the water } \\
\text { step at Klekotki } \\
-41+660 \mathrm{~km}\end{array}$ & 83,20 & 85,50 & - & 1,7 \\
\hline
\end{tabular}

według załącznika nr 6 do Rozporæqdzenia Ministra Środowiska z dnia 9 listopada $2011 \mathrm{r}$. w sprawie klasyfikacji stanu ekologicznego, potencjatu ekologicznego i stanu chemicznego jednolitych części wód powierzchniowych (Dz. U. poz. 1549) zaliczono do typu rzeki nizinnej żwirowej (nr 20). Jednolita część wód „Wąska od Sały do wpływu do jeziora Drużno" obejmuje z kolei środkowy i dolny odcinek rzeki. Zlewnia jednolitych części wód zajmuje powierzchnię 40 km², w której długość cieku wynosi 23,4km (Koniecka, Gębka 2015). Sama rzeka według powyższego rozporządzenia zaliczana jest do typu potoku lub strumienia na obszarze będącym pod wpływem procesów torfotwórczych (nr 23). Analizowane stawy zlokalizowane są jedynie w odcinku rzeki o typie rzeki nizinnej żwirowej.

Obiekt Stawowy Markowo-Podony położony jest w górnym odcinku rzeki Wąskiej (ryc. 2). Jego granicę wyznaczają - budowla piętrząca jeziora Zimnochy i Okonie Nr 4 oraz budowla piętrząca Nr 1 przy zbiorniku w Klekotkach.

Obiekt Stawowy obejmuje obszar 65,97 ha (powierzchnia użytkowa wynosi 51,85 ha). Zlokalizowanych jest tu 14 stawów oraz 5 magazynów. Pobór i zrzut wody z gospodarstwa regulowany jest przez budowle piętrzące zlokalizowane na rzece Wąskiej, 


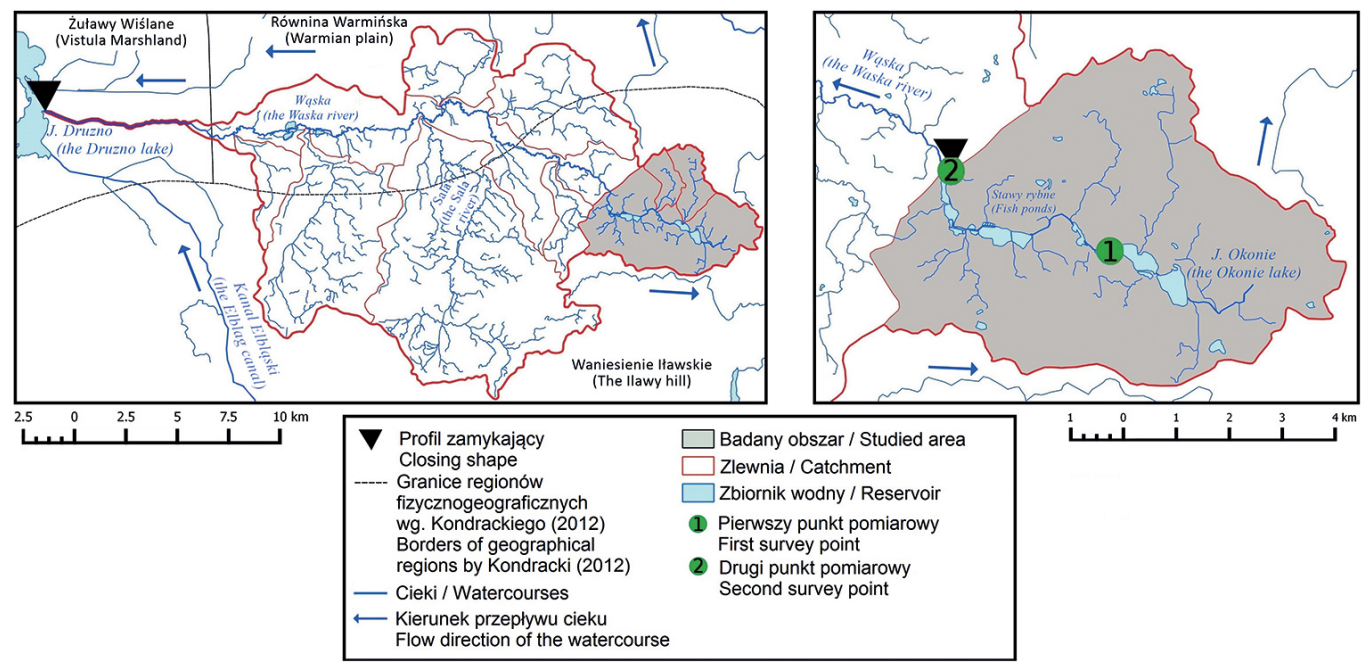

Ryc. 1. Badany obszar na tle regionów fizycznogeograficznych Kondrackiego (2012) oraz lokalizacja stawów hodowlanych i punktów pomiarowych w zlewni

Fig. 1. Study area against the background of physico-geographical regions by Kondracki (2012) and the location of breeding ponds and measurment points in the catchment

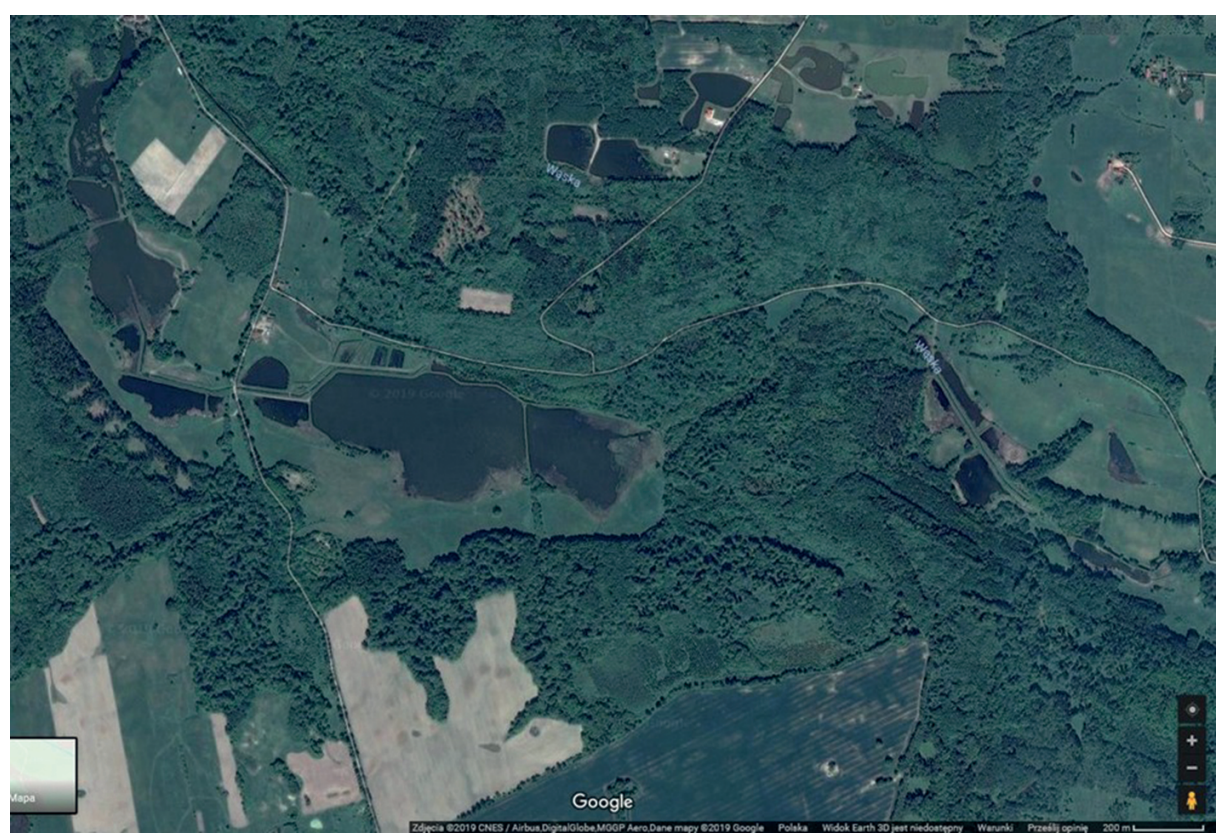

Ryc. 2. Lokalizacja stawów rybnych Markowo-Podony (geoportal.gov.pl)

Fig. 2. Location of the Markowo-Podony fish ponds (geoportal.gov.pl) 


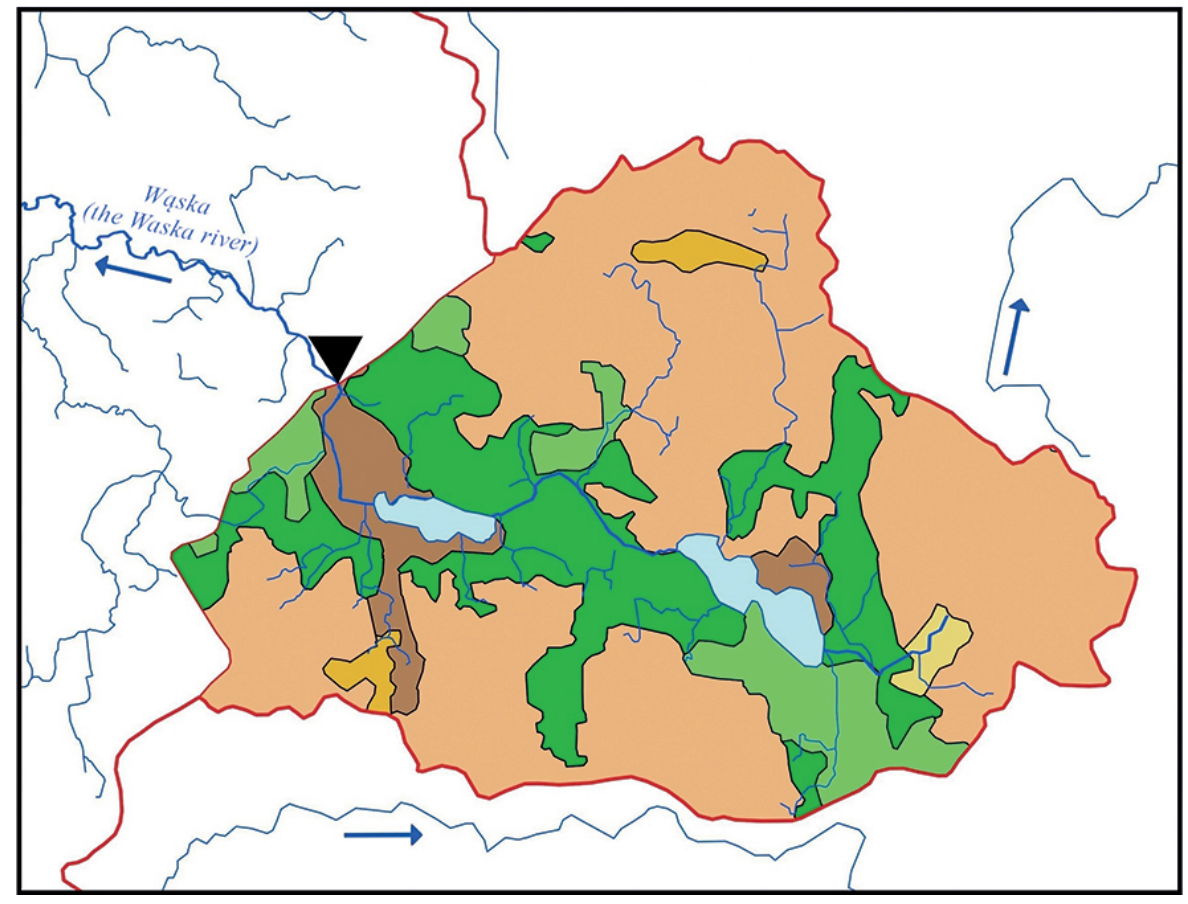

Profil zamykający

Closing shape

- Cieki / Watercourses

$\longleftarrow$ Kierunek przepływu cieku Flow direction of the watercourse

$\square$ Dział wodny / Watershed

Grunty orne poza zasięgiem urządzeń nawadniających Arable land beyond the reach of irrigation devices

Łąki, pastwiska / Fields, pastures

Złożone systemy upraw i działek Complex crop systems and plots

Tereny zajęte głównie przez rolnictwo z dużym udziałem roślinności naturalnej Mainly agricultural areas with natural vegetation Lasy liściaste / Deciduous forests

Lasy mieszane / Mixed forests

Zbiorniki wodne / Reservoirs

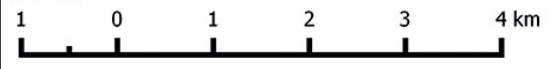

Ryc. 4. Formy pokrycia terenu badanego obszaru

Fig. 4. Land use in the study area 
a także dzięki systemowi rozrządu wody na poszczególne stawy wraz z kilkunastoma mnichami wpustowymi i spustowymi. Napełnianie stawów następuje co roku w okresie od 2 do 10 listopada. Natomiast zrzut wody ze wszystkich stawów odbywa się co roku od 15 września do 30 października. Podczas odprowadzania wody ze stawów zrzut wody nie powinien przekraczać $0.40 \mathrm{~m}^{3} \cdot \mathrm{s}^{-1}$ (Gospodarstwo Rybackie Klekotki).

Na terenie gospodarstwa znajdują się 4 zastawki piętrzące (tab. 1); groble ziemne o szerokości skarpy $4 \mathrm{~m}$, nachyleniu skarp n = 1:1,5 i łącznej długości 4,5 km; oraz mnichy wypustowe -20 szt., $\varnothing$ od $30 \mathrm{~cm}$ do $60 \mathrm{~cm}$; i wypustowe -20 szt., $\varnothing$ od $30 \mathrm{~cm}$ do $100 \mathrm{~cm}$ (Kelles-Krauz 2016).

\section{Metody}

Badania terenowe przeprowadzono w okresie od 15 listopada 2014 do 21 listopada 2015 r. Odbywały się one z dwumiesięcznym interwałem. Był to wystarczający przedział czasu do prześledzenia zmienności chemizmu środowiska wodnego rzeki Wąskiej, który uwzględniał zmieniające się warunki hydrometeorologiczne.

Próbki wody do analizy laboratoryjnej pobierano w dwóch punktach. Pierwszy umiejscowiony został powyżej (ponad $2 \mathrm{~km}$ ) analizowanego obiektu, drugi natomiast kilkaset metrów poniżej zrzutu wód poprodukcyjnych ze stawów (ryc. 1). Taki układ punktów pomiarowych umożliwiał wzajemne ich porównanie oraz określenie, jakiej jakości woda wpływa w granice całego kompleksu, a jaka uwalniana jest przez zastawkę. Próbki wody pobierane z terenu zostały przetransportowane do laboratorium Katedry Hydrologii Uniwersytetu Gdańskiego.

Pobrane próbki poddano analizie opartej na zbadaniu wybranych wskaźników fizyczno-chemicznych. Za pomocą chromatografu jonowego Dionex C1100 zbadane zostały azotany(V) i fosforany(V), przy wykorzystaniu normy PN-EN ISO 10304-1 z 2009 r. oraz siarczany(VI) przy użyciu normy PN-EN ISO 10304-1 z 2009 r. Stężenia amoniaku (M042 PB-1:2018), azotu ogólnego (M043 PB-1:2016) i fosforu ogólnego (PN-EN ISO 6878:2006) otrzymano, używając metody spektrofotometrycznej przy wykorzystaniu spektrofotometru Nova 400. Analizie poddano łącznie 62 próbki wody.

Jakość wody w rzece Wąskiej powyżej i poniżej zrzutu wody określono zgodnie z wytycznymi zawartymi w Rosporsqdzeniu Ministra Środowiska \& 2016 r. w sprawie sposobu klasyfikacji stanu jednolitych części wód powierzchniowych ora środowiskowych norm jakości dla substancji priorytetowych. Ponadto w miejscach poboru wody wykonano pomiar wydajności przepływu, który posłużył do obliczenia ładunków zanieczyszczeń (Bogdanowicz 2004). Pomiary przepływów zostały wykonane za pomocą metody punktowej wykorzystującej młynek hydrometryczny (Valeport model 801), natomiast ładunki chwilowe obliczono za pomocą wzoru: 


\section{$\mathrm{Li}=\mathrm{Ci} \cdot \mathrm{Qi}$,}

gdzie:

$\mathrm{Ci}$ - stężenie wskaźników $\left[\mathrm{mg} \cdot \mathrm{dm}^{3}\right]$;

Qi - natężenie przepływu w czasie poboru próbek $\left[\mathrm{m}^{3} \cdot \mathrm{s}^{-1}\right]$.

Do obliczenia ładunków jednostkowych skorzystano z następującego wzoru:

$$
\mathrm{E}=\mathrm{La} / \mathrm{A}
$$

gdzie:

La - miesięczny ładunek $\left[\mathrm{kg} \cdot \mathrm{miesiąc}^{-1}\right]$;

A - powierzchnia zlewni $\left[\mathrm{km}^{2}\right]$.

\section{Uzyskane wyniki i dyskusja}

Ogólny stan wody doprowadzanej do stawów hodowlanych można określić jako dobry, podobnie jej potencjał ekologiczny. Większość przeanalizowanych wskaźników spełnia normy kwalifikujące je jako stan bardzo dobry.

Tab. 2. Zakres i średnie wartości wskaźników fizyczno-chemicznych oraz klasa jakości wody rzeki Wąskiej powyżej (punkt 1) i poniżej (punkt 2) stawów hodowlanych

Table 2. Range and average values of physicochemical indices and water quality class of the Wąska river above (point 1) and below (point 2) the ponds

\begin{tabular}{|c|c|c|c|c|c|c|}
\hline \multirow{3}{*}{$\begin{array}{l}\text { Wskaźnik } \\
\text { Indicator }\end{array}$} & \multicolumn{2}{|c|}{$\begin{array}{l}\text { Zakres } \\
\text { Range }\end{array}$} & \multicolumn{2}{|c|}{$\begin{array}{l}\text { Średnia } \\
\text { Average }\end{array}$} & \multirow{2}{*}{\multicolumn{2}{|c|}{$\begin{array}{l}\text { Wartość graniczna wskaźnika dla } \\
\text { klasy (Rozporządzenie MS 2016) } \\
\text { Limit value of the indicator for } \\
\text { a class (Regulation of MS 2016) }\end{array}$}} \\
\hline & \multicolumn{4}{|c|}{$\begin{array}{l}\text { Punkt pomiarowo-kontrolny } \\
\text { Measurment and control point }\end{array}$} & & \\
\hline & 1 & 2 & 1 & 2 & 1 & II \\
\hline $\begin{array}{l}\text { Azot ogólny } \\
\text { Total nitrogen }\end{array}$ & $0,95-2,69$ & $0,7-2,05$ & 1,89 & 1,25 & $\leq 2,0$ & $\leq 4,1$ \\
\hline $\begin{array}{c}\text { Amoniak } \\
\text { Ammonia }\end{array}$ & $\begin{array}{c}\text { n.w. }-1,18 \\
\text { w.n.f. }-1.18 \\
\end{array}$ & $\begin{array}{c}\text { n.w. }-0,62 \\
\text { w.n.f. }-0.62 \\
\end{array}$ & 0,77 & 0,37 & $\leq 0,13$ & $\leq 0,563$ \\
\hline $\begin{array}{l}\text { Azotany(V) } \\
\text { Nitrates }\end{array}$ & $\begin{array}{r}\text { n.w. }-9,49 \\
\text { w.n.f. }-9.49\end{array}$ & $0,02-7,81$ & 2,65 & 1,42 & $\leq 1,0$ & $\leq 2,4$ \\
\hline $\begin{array}{l}\text { Fosforany(V) } \\
\text { Phosphates }\end{array}$ & $\begin{array}{c}\text { n.w. }-1,39 \\
\text { w.n.f. }-1.39\end{array}$ & $\begin{array}{c}\text { n.w. }-0,99 \\
\text { w.n.f. }-0.99\end{array}$ & 0,57 & 0,41 & $\leq 0,065$ & $\leq 0,101$ \\
\hline $\begin{array}{l}\text { Siarczany }(V I) \\
\text { Sulfates }\end{array}$ & $6,53-55,25$ & $3,56-29,14$ & 32,29 & 16,25 & $\leq 28,4$ & $\leq 74,5$ \\
\hline
\end{tabular}

Objaśnienia: n.w. - nie wykryto.

Explanations: w.n.f. - was not found. 
Rozpatrując badane wskaźniki, można zauważyć, że dla azotu ogólnego oraz siarczanów(VI) uzyskane wyniki w obu punktach pomiarowych klasyfikowały wody Wąskiej do I i II klasy jakościowej, z tym że w punkcie 2 przekroczenia dla klasy I były nieznaczne (tab. 2). Z kolei wskaźnikami przekraczającymi dopuszczalne stężenia są fosforany(V), azotany(V) i amoniak (tab. 2). Uzyskane wyniki klasyfikują wody w obu punktach pomiarowych do grupy niespełniającej wymogów II klasy jakościowej, z tym że w punkcie 2 amoniak przekraczał normy II klasy w nieznacznym stopniu (tab. 2). Oczywiście w zależności od sezonu możliwe są wartości klasyfikujące wody w obu punktach pomiarowych do I lub II klasy czystości. Należy nadmienić, że w przypadku fosforu w stawach ważne jest, że występuje on w postaci rozpuszczonego fosforu organicznego oraz jonów fosforanowych. Głównym jego zadaniem jest regulacja produkcji biologicznej, przez co wpływa on na żyzność wód (Dojlido 1995).

\section{Stężenia wybranych wskaźników chemicznych}

Stężenie fosforanów $(\mathrm{V}) \mathrm{w}$ okresie badań wyniosło średnio $0,57 \mathrm{mg} \cdot \mathrm{dm}^{-3}$ powyżej stawów i $0,41 \mathrm{mg} \cdot \mathrm{dm}^{-3}$ poniżej. W tym czasie zaobserwowano duże wahania stężeń w różnych okresach roku hydrologicznego (ryc. 3).

Dwukrotnie (zarówno powyżej, jak i poniżej gospodarstwa) podczas analizy laboratoryjnej nie wykryto nawet śladowych ilości fosforanów $(\mathrm{V}) \mathrm{w}$ badanych próbkach (ryc. 3). Dla punktu 1 były to miesiące: marzec i lipiec 2015 r., z kolei dla punktu 2: listopad 2014 r. i lipiec 2015 r. Pod koniec 2015 r. zaobserwowano znaczny wzrost ilości fosforanów(V) w wodach powierzchniowych doprowadzanych i wyprowadzanych ze stawów rybnych. Maksymalna wartość stężenia fosforanów(V) w wodach powierzchniowych odnotowana w punkcie 1 we wrześniu $\left(1,39 \mathrm{mg} \cdot \mathrm{dm}^{-3}\right)$ ponad 13-krotnie przewyższała wartość dopuszczalną ustaloną w Rozporæqdæeniu Ministra Środowiska 2016 r. w sprawie sposobu klasyfikacji stanu jednolitych cæęści wód powier wchniowych oraz środowiskowych norm jakości dla substancji priorytetowych. Zastanawiający jest fakt nagłego wystąpienia tak wysokich stężeń tego jonu. Ze względu na rolniczy charakter zlewni, w której znajduje się analizowany obszar, prawdopodobną przyczyną takiego stanu może być nadmierne stosowanie nawozów fosforowych. Taki rodzaj wykorzystania obszaru (ryc. 4) powoduje, że ilość związków fosforu w punkcie 1, który znajduje się w bezpośrednim sąsiedztwie z użytkami rolniczymi, jest względnie duża.

Związki fosforu są wprowadzane do rzeki ze spływem powierzchniowym i podziemnym (Dojlido 1995). Do podwyższenia stężeń fosforanów(V) mogły przyczynić się także domki letniskowe usytuowane kilkaset metrów powyżej punktu pomiarowego, w miejscowości Zimnochy nad jeziorem Wiskie. 


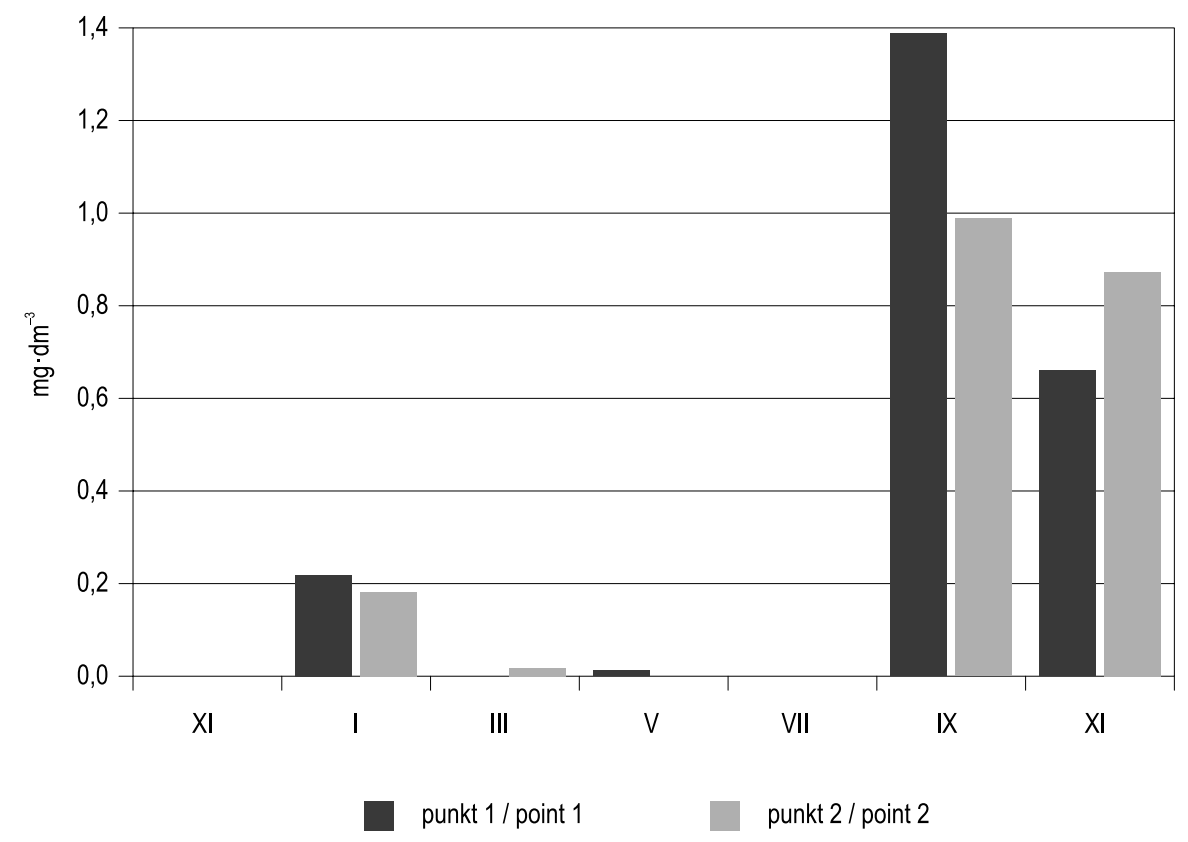

Ryc. 3. Zmiany stężeń fosforanów(V) w wodach rzeki Wąska w roku hydrologicznym 2015 Fig. 3. Changes in phosphate concentrations in the Wąska river waters in the hydrological year 2015

W podobny sposób kształtują się stężenia fosforanów(V) zaprezentowane przez Kanownika i Wiśnios (2015) dla rzeki Rudawy. Prowadzili oni badania w bliźniaczo podobnej zlewni o dominującym rolniczym użytkowaniu. Wyniki otrzymane z przebadanych próbek wykazały, że woda rzeki Rudawy nie odpowiada normom wód śródlądowych, a parametrami niespełniającymi wymogów były azotany(V) i fosforany (V). Stężenia fosforanów(V) wahały się w zakresie od 0,24 do 1,99 $\mathrm{mg} \cdot \mathrm{dm}^{-3}$. Podobnie jak na Wąskiej, tutaj także odnotowano nieznaczny spadek ilości fosforanów(V) poniżej gospodarstwa. W wodzie doprowadzanej do stawów średnie stężenie tego jonu wynosiło $0,79 \mathrm{mg} \cdot \mathrm{dm}^{-3}$, natomiast w punkcie poniżej stawów stężenia zmalały i wynosiły $0,53 \mathrm{mg} \cdot \mathrm{dm}^{-3}$.

Wśród badanych wskaźników zaobserwowano takie, których jakość poprawia się poniżej zrzutu wody ze stawów rybnych. Należą do nich: azot ogólny, amoniak, $\operatorname{azotany}(\mathrm{V})$ oraz siarczany(VI).

Azot ogólny jest sumą azotu organicznego, amonowego, azotanowego oraz azotynowego (Dojlido 1995). Nadmierna jego ilość prowadzi do procesu eutrofizacji (Bogdał, 
Ostrowski 2007). Jak wykazały badania terenowe, wskaźnik ten w przypadku rzeki Wąskiej nie wpływa w znaczny sposób na jej cechy fizyczno-chemiczne powyżej i poniżej omawianych zbiorników. Średnie stężenie tego jonu w wodzie doprowadzanej do stawów rybnych wyniosło zaledwie $1,89 \mathrm{mg} \cdot \mathrm{dm}^{-3}$. Poniżej zrzutu wody stężenie było o 0,64 mg niższe (tab. 2). Podobna sytuacja dotyczy obliczonej mediany. Uzyskana wartość powyżej zbiorników wyniosła $1,50 \mathrm{mg} \cdot \mathrm{dm}^{-3}$, zaś poniżej $1,15 \mathrm{mg} \cdot \mathrm{dm}^{-3}$. Rozpiętość stężeń azotu ogólnego w okresie badań wahała się od $0,7 \mathrm{mg} \cdot \mathrm{dm}^{-3}$ (XI 2015) do 2,69 $\mathrm{mg} \cdot \mathrm{dm}^{-3}$ (III 2015) w obu punktach pomiarowych (ryc. 5).

Z kolei średnia zawartość azotanów(V) kształtowała się na poziomie 2,65 $\mathrm{mg} \cdot \mathrm{dm}^{-3}$ powyżej stawów i $1,42 \mathrm{mg} \cdot \mathrm{dm}^{-3}$ poniżej (tab. 2). Największy spadek stężeń tego jonu w wodzie zauważono w styczniu i wynosił aż $2,30 \mathrm{mg}$. W punkcie 1 było to aż 9,49 $\mathrm{mg} \cdot \mathrm{dm}^{-3}$, natomiast w drugim $7,81 \mathrm{mg} \cdot \mathrm{dm}^{-3}$. We wrześniu z kolei notuje się niewielki wzrost ilości azotanów o $0,31 \mathrm{mg} \mathrm{w}$ stosunku do punktu 1, w którym stężenie wynosiło $0,39 \mathrm{mg} \cdot \mathrm{dm}^{-3}$.

Także stężenia amoniaku dobrze uwidaczniają retencyjną działalność stawów rybnych. Stężenia tego jonu w wodach powierzchniowych dochodzą do kilku $\mathrm{mg} \cdot \mathrm{dm}^{-3}$.

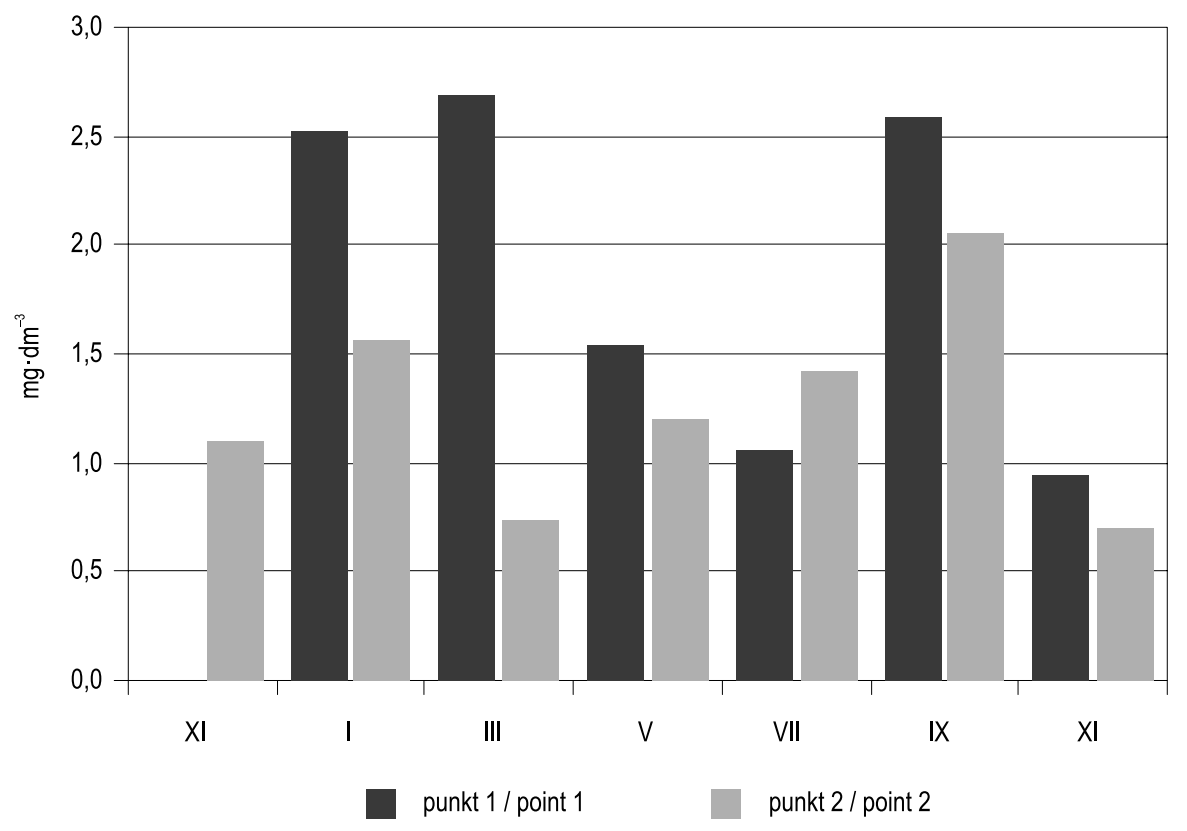

Ryc. 5. Zmiany stężeń azotu ogólnego w wodach rzeki Wąska w roku hydrologicznym 2015 Fig. 5. Changes in total nitrogen concentrations in the waters of the Wąska river in the hydrological year 2015 
Pochodzi on z różnych źródeł, z których najważniejszymi są: rozwój roślinności wodnej oraz dopływ ze źródeł punktowych (Dojlido 1995). Stężenia amoniaku w punkcie 1 nie były duże i średnio wyniosły $0,77 \mathrm{mg} \cdot \mathrm{dm}^{-3}$. W punkcie 2 stężenie wyniosło już tylko $0,37 \mathrm{mg} \cdot \mathrm{dm}^{-3}$. W przypadku amoniaku można mówić o pewnego rodzaju retencji zanieczyszczeń z uwagi na dobrą rozpuszczalność tego jonu w wodzie. Możliwe, iż hodowla w 2015 r. była ograniczona z uwagi na suszę hydrologiczną, a w związku z tym pobierano mniejsze ilości wody na potrzeby stawów.

Siarczany(VI) powszechnie występują w wodach powierzchniowych. Ich stężenia wahają się zwykle między $10-80 \mathrm{mg} \cdot \mathrm{dm}^{-3}$. Do wód przedostają się z opadów atmosferycznych, w wyniku wymywania skał i gleb, a także ze ściekami komunalnymi i przemysłowymi (Dojlido 1995). Wody wykorzystywane do zasilania opisywanych zbiorników cechowały się niewielkimi stężeniami siarczanów (ryc. 6). Średnia ilość tego jonu w punkcie 1 wyniosła $32,29 \mathrm{mg} \cdot \mathrm{dm}^{-3}$, natomiast w punkcie $2-16,25 \mathrm{mg} \cdot \mathrm{dm}^{-3}$ (tab. 2). Z kolei mediana w punkcie 1 wyniosła $36,00 \mathrm{mg} \cdot \mathrm{dm}^{-3}$, natomiast w punkcie 2 zaledwie $17,00 \mathrm{mg} \cdot \mathrm{dm}^{-3}$.



Ryc. 6. Zmiany stężeń siarczanów(VI) w wodach rzeki Wąska w roku hydrologicznym 2015 Fig. 6. Changes in sulfate concentrations in the Wąska river waters in the hydrological year 2015 


\section{Wielkość ładunków}

Tendencję malejącą omawianych jonów w przejrzysty sposób obrazują obliczone na potrzeby pracy ładunki chwilowe i jednostkowe. Wszystkie wskaźniki, z wyjątkiem azotanów(V), prezentują niższe wartości poniżej stawów hodowlanych.

Ładunki chwilowe azotu ogólnego w punkcie 1 kształtowały się na poziomie $0,11 \mathrm{mg} \cdot \mathrm{s}^{-1}$, natomiast w punkcie 2 maleją o połowę $\left(0,06 \mathrm{mg} \cdot \mathrm{s}^{-1}\right)$. Z kolei ładunki jednostkowe wahały się w granicach od 0,12 do 16,11 ton $\cdot$ miesiąc ${ }^{-1} \mathrm{w}$ punkcie 1 i od 0,41 do 13,81 ton $\cdot$ miesiąc $^{-1} \mathrm{w}$ punkcie 2 .

W punkcie 1 zanotowano wielkość ładunków chwilowych amoniaku na poziomie $0,02 \mathrm{mg} \cdot \mathrm{s}^{-1}$ (ładunki jednostkowe w tym punkcie kształtowały się w granicach 4,00 ton $\cdot \mathrm{miesiąc}^{-1}$ ), natomiast $\mathrm{w}$ punkcie $2-0,01 \mathrm{mg} \cdot \mathrm{s}^{-1}$ (ładunki jednostkowe w punkcie 2 wynosiły od 0,00 do 3,07 ton $\cdot$ miesiąc $^{-1}$ ).

Również ładunki chwilowe siarczanów(VI) malały i wynosiły kolejno $1,34 \mathrm{mg} \cdot \mathrm{s}^{-1}$ w punkcie 1 i $0,72 \mathrm{mg} \cdot \mathrm{s}^{-1} \mathrm{w}$ punkcie 2. Ładunki jednostkowe dla siarczanów (VI) w tych punktach pomiarowych wynosiły $0,50-343,70$ ton $\cdot$ miesiąc $^{-1} \mathrm{w}$ punkcie 1 i 8,76-160,36 ton $\cdot$ miesiąc $^{-1} \mathrm{w}$ punkcie 2.

$\mathrm{Z}$ kolei ładunki chwilowe fosforanów(V) w punkcie 1 wynosiły $0,03 \mathrm{mg} \cdot \mathrm{s}^{-1}$, a w punkcie $20,02 \mathrm{mg} \cdot \mathrm{s}^{-1}$. Ładunki jednostkowe kształtowały się tu na poziomie 0,00-8,65 ton $\cdot \mathrm{miesiąc}^{-1}$ (punkt 1) i 0,00-4,45 ton $\cdot \mathrm{miesiąc}^{-1}$ (punkt 2).

Jedynie ładunki chwilowe azotanów(V) nie uległy zmianie. Średni ładunek doprowadzany do stawów rybnych oraz zrzucany wyniósł $0,14 \mathrm{mg} \cdot \mathrm{s}^{-1}$. Ładunki jednostkowe dla azotanów(V) w okresie badań wyniosły $0,00-41,62$ ton $\cdot$ miesiąc $^{-1}$ (punkt 1) i 0,01 - 69,13 ton·miesiąc ${ }^{-1}$ (punkt 2). Należy jednak pamiętać, że wielkość ładunków jest iloczynem stężenia określonego wskaźnika chemicznego i wielkości przepływu, w związku z czym może on ulegać dużej dynamice zmian. Drabiński (1991), analizując wpływ gospodarki stawowej na odpływ ze zlewni Baryczy, ocenił, że był on wyższy podczas jesiennego opróżniania stawów o $100 \%$ w stosunku do średniej wieloletniej. Tak więc może on spowodować zaburzenia w wielkości ładunku zanieczyszczeń.

Dynamika transportu biogenów „dostarczanych” i „,wypuszczanych” z gospodarstwa cechuje się wyraźnym zróżnicowaniem sezonowym. Porównanie ładunków azotu ogólnego (ryc. 7) przepływających przez stawy w roku hydrologicznym 2015 w półroczu letnim i zimowym wskazuje, że zróżnicowanie sezonowe odzwierciedla odmienne warunki hydrologiczne w półroczach. W okresie zimowym do stawów dociera 58\% puli ładunków azotu ogólnego, wprowadzanej w ciągu całego roku hydrologicznego. W przypadku wody spływającej ze stawów jest to $61 \%$.

W przypadku fosforu ogólnego dysproporcje te są znacznie większe - w półroczu zimowym rzeka Wąska dostarcza do stawów $65 \%$ rocznego ładunku. Z gospodarstwa wypływa natomiast $62 \%$ rocznego ładunku. Najwyższe ładunki wpływające 


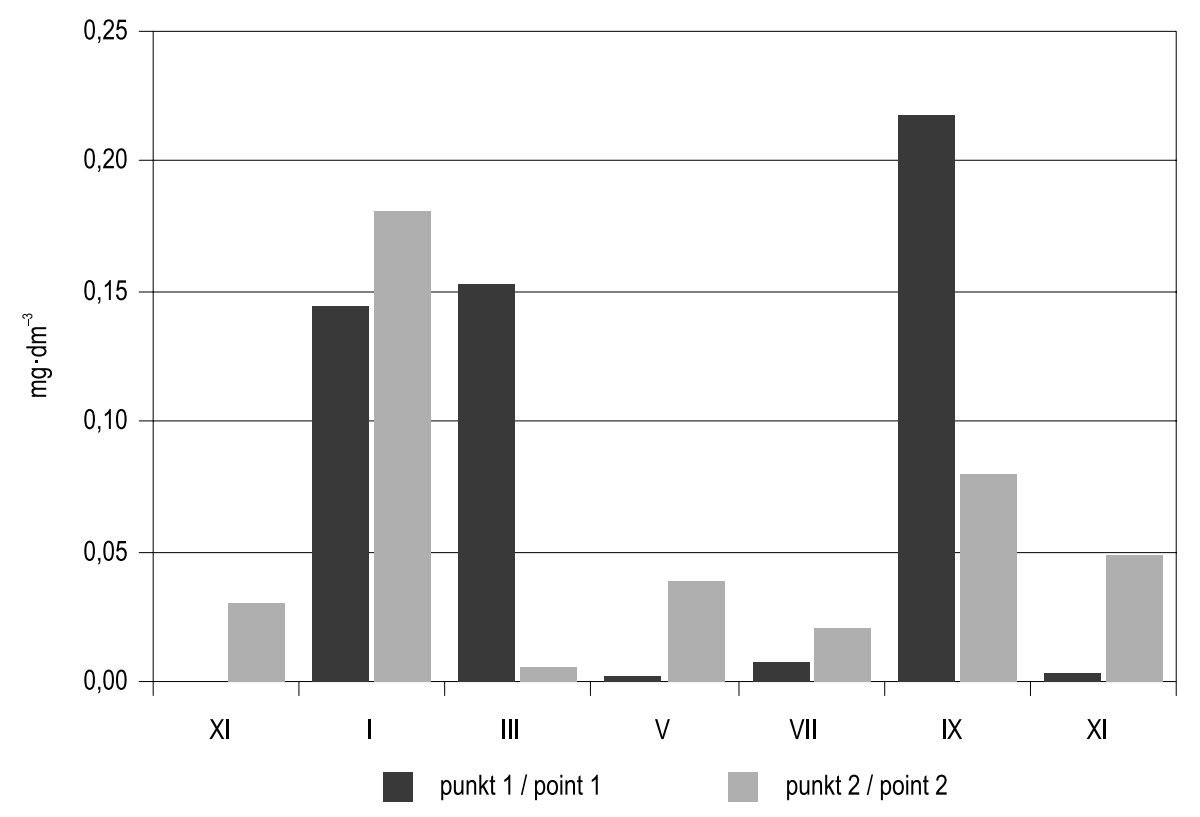

Ryc. 7. Wielkości ładunków chwilowych azotu ogólnego w wodach rzeki Wąska w roku hydrologicznym 2015

Fig. 7. Magnitude of instantaneous nitrogen loads in the waters of the Wąska river in the hydrological year 2015

i wydostające się z gospodarstwa przypadają na okres zimowy i początek jesieni. Może to być spowodowane nawożeniem pól uprawnych nawozami lub brakiem rozwoju roślin w okresie zimy, a także zrzutem wody ze stawów.

Podczas prac terenowych dokonano wywiadu lokalnego, z którego wynika, że miejscowi rolnicy wykorzystują $200 \mathrm{~kg}$ nawozów azotowych na 1 ha ziemi. Maksymalne ładunki wpływające do stawów zanotowano we wrześniu - 0,22 $\mathrm{mg} \cdot \mathrm{s}^{-1}$, chociaż podwyższone wartości zaobserwowano także w styczniu $-0,14 \mathrm{mg} \cdot \mathrm{s}^{-1} \mathrm{i}$ marcu $-0,15 \mathrm{mg} \cdot \mathrm{s}^{-1}$. Maksymalne ładunki chwilowe wypływające ze stawów odnotowano w styczniu $0,18 \mathrm{mg} \cdot \mathrm{s}^{-1}$. Minimum natomiast przypada na maj $\left(0,002 \mathrm{mg} \cdot \mathrm{s}^{-1} \mathrm{~W}\right.$ punkcie 1 i $0,039 \mathrm{mg} \cdot \mathrm{s}^{-1} \mathrm{w}$ punkcie 2$)$ i lipiec $\left(0,007 \mathrm{mg} \cdot \mathrm{s}^{-1} \mathrm{w}\right.$ punkcie 1 i $0,020 \mathrm{mg} \cdot \mathrm{s}^{-1} \mathrm{w}$ punkcie 2$)$.

Rozpatrując wielkości odpływu w punktach pomiarowych (tab. 3) z wartościami ładunków azotu ogólnego, można stwierdzić, że istnieje silna zależność między ładunkiem azotu ogólnego a odpływem w ciągu całego roku hydrologicznego. Ilnicki (2002) zauważył, że istnieje związek wielkości ładunku azotu wymywanego ze zlewni z wielkością średniego przepływu rocznego. Jest to wynik procesu 
Tabela 3. Wartości przepływów na rzece Wąskiej w punktach pomiarowych Table 3. Values of discharge of the Wąska river at measurement points

\begin{tabular}{|c|c|c|c|c|c|c|c|}
\hline \multirow{2}{*}{$\begin{array}{c}\text { Punkt pomiarowy } \\
\text { Measurment point }\end{array}$} & \multicolumn{10}{|c|}{ Q $\left[\mathrm{dm}^{3} \cdot \mathrm{s}^{-1}\right]$} \\
\cline { 2 - 8 } & $\mathrm{XI} 2014$ & $\mathrm{I} 2015$ & $\mathrm{III} 2015$ & $\mathrm{~V} 2015$ & $\mathrm{VII} 2015$ & $\mathrm{IX} 2015$ & $\mathrm{XI} 2015$ \\
\hline 1 & 20,1 & 57,3 & 56,9 & 1,0 & 6,8 & 84,0 & 3,7 \\
\hline 2 & 27,3 & 115,7 & 7,2 & 32,2 & 13,8 & 39,0 & 69,1 \\
\hline
\end{tabular}

wymywania związków azotu z profilu glebowego do wód powierzchniowych i gruntowych w formie jonowej (rozpuszczonej).

Odpływ wody z obszaru badań nie wpisuje się w ogólny opis zasilania atmosferycznego. Rodzaj zasilania w okresie letnim i zimowym decyduje o różnym kształtowaniu się odpływu. Początek roku hydrologicznego 2015 poprzedzały niskie stany wody, które były skutkiem recesji zasilania podziemnego. W półroczu zimowym, szczególnie w styczniu (22 dni z opadem), na obszar zlewni dotarły opady w postaci deszczu i śniegu. Niestety, powstała pokrywa śnieżna uległa prawie natychmiastowemu stopieniu, zasilając tym samym wody rzeki Wąskiej. Brak zatorów śryżowych czy spiętrzeń lodowych na rzece przyczynił się do zmniejszenia stanu wody. Tak szybkie topnienie poskutkowało brakiem retencji wody w pokrywie śnieżnej, a co za tym idzie, nie zostały one włączone w okresie wiosennym do obiegu (Piętka 2009).

Maksymalny przepływ (średnio $86,5 \mathrm{dm}^{3} \cdot \mathrm{s}^{-1}$ ) wystąpił w styczniu (dane własne). Jest to spowodowane stosunkowo wysoką temperaturą jak na ten miesiąc, dzięki której następowało natychmiastowe topnienie zalegającego śniegu i spływ powierzchniowy zasilający tym samym rzekę Wąską. Średnia temperatura w styczniu 2015 r. wynosiła $0,2^{\circ} \mathrm{C}$. Najmniejszym przepływem odznaczał się lipiec $\left(10,3 \mathrm{dm}^{3} \cdot \mathrm{s}^{-1}\right)$, który był najbardziej deszczowym miesiącem w analizowanym roku hydrologicznym (18 dni z deszczem i 88,0 mm opadu). Ponadto w 2015 r. wystąpiły dwa wezbrania. Pierwsze, to wspomniane już maksimum styczniowe, natomiast drugie, które wyniosło średnio $61,5 \mathrm{dm}^{3} \cdot \mathrm{s}^{-1}$, zaobserwowano we wrześniu, podczas jesiennego zrzutu wody ze stawów.

W nieco inny sposób wygląda relacja ładunku fosforu ogólnego do wielkości odpływu wody ze zlewni. Silniejsza zależność odnotowana została w punkcie 1 dla półrocza zimowego (większa niż w przypadku ładunku azotu ogólnego), natomiast słabsza dla półrocza letniego. Podobnie jak w przypadku ładunku azotu ogólnego, tutaj również największe wartości ładunków wpadających i spływających z gospodarstwa przypadają na okres zimowy (styczeń) i początek jesieni (wrzesień). Maksimum przypada na styczeń i dla ładunków wpływających wynosi $0,0085 \mathrm{mg} \cdot \mathrm{s}^{-1}$, natomiast wypływających $0,0156 \mathrm{mg} \cdot \mathrm{s}^{-1}$. Podwyższone wartości zaobserwowano także we wrześniu - 0,0074 $\mathrm{mg} \cdot \mathrm{s}^{-1}$ dla ładunków mierzonych w punkcie 1 i $0,0053 \mathrm{mg} \cdot \mathrm{s}^{-1} \mathrm{dla}$ ładunków mierzonych w punkcie 2. Minimalne ładunki chwilowe wpływające do 


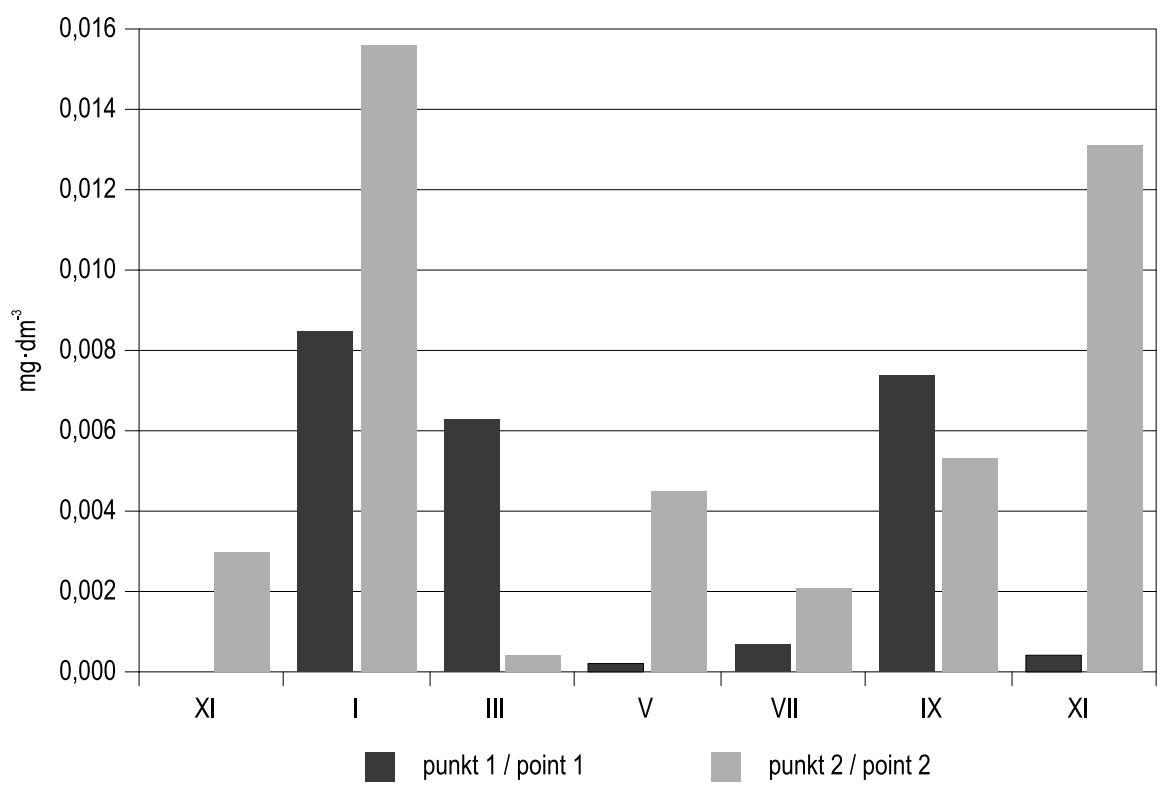

Ryc. 8. Ładunki chwilowe fosforu ogólnego w wodach rzeki Wąska w roku hydrologicznym 2015 Fig. 8. Instantaneous phosphorus loads in the waters of the Wąska river in the hydrological year 2015

stawów zanotowano w maju - 0,0002 $\mathrm{mg} \cdot \mathrm{s}^{-1}$, natomiast minimalne ładunki wypływające ze stawów odnotowano w marcu $0,0004 \mathrm{mg} \cdot \mathrm{s}^{-1}$ (ryc. 8).

Związki fosforu do wód powierzchniowych przedostają się wraz z cząsteczkami koloidalnymi gleby, co powoduje, że wielkość ładunku fosforu nie jest zależna jedynie od odpływu, ale również od rumowiska unoszonego (Ilnicki 2002). Zaobserwowany wzrost wielkości ładunku fosforu w okresie zimy może być spowodowany przez wystąpienie opadów powodujących erozję gleby (opady nawalne wywołujące gwałtowne wezbrania). W 2015 r. hydrologicznym było 14 dni, w których zanotowano opad deszczu i 8 dni ze śniegiem. Łącznie w tych dniach odnotowano $50,5 \mathrm{~mm}$ opadu atmosferycznego.

Ogólny ładunek biogenów może być determinowany przez czynniki takie jak np.: ilość zawiesin, natężenie przepływu czy warunki hydrometeorologiczne (Russell i in. 1998). Popek i in. (2014) stwierdzili, że zależność ta jest szczególnie widoczna w okresie wezbrań opadowych. Jak już wcześniej zostało zaznaczone, podwyższone stany przepływu chwilowego w roku hydrologicznym 2015 wystąpiły w styczniu - średnio $86,5 \mathrm{dm}^{3} \cdot \mathrm{s}^{-1}$ i wrześniu - średnio $61,5 \mathrm{dm}^{3} \cdot \mathrm{s}^{-1}$. 
Niestety zależności tej nie potwierdzają stany wody, które w tych miesiącach na stacji w Pasłęku (dane IMGW-PIB) wynosiły kolejno: w styczniu - 416,70 mm, we wrześniu - 419,39 mm, dla średniej rocznej równej 421,06 mm. Na ilość transportowanych rzeką Wąską zanieczyszczeń w formie zawieszonej może mieć wpływ również nielegalny zrzut ścieków z wcześniej wspomnianych domków letniskowych. Niemniej jednak w tym przypadku stwierdzono słaby związek między zawartością fosforu i zawiesiny.

Pozostałe wskaźniki takie jak: amoniak, azotany i siarczany nie przejawiały szczególnych zmian sezonowych. Stężenia tych jonów nie przekraczały również norm jakościowych.

\section{Wnioski}

Analiza stężeń badanych wskaźników fizyczno-chemicznych w wodzie rzeki Wąskiej zasilającej stawy rybne w Klekotkach wykazała, że:

1. Największy wpływ na pogorszenie się jakości wody rzeki Wąskiej na odcinku powyżej i poniżej stawów rybnych mają stężenia fosforanów.

2. Jakość wody w rzece Wąskiej jest ściśle powiązana z użytkowaniem terenu w najbliższym sąsiedztwie rzeki. Grunty orne położone poza zasięgiem urządzeń nawadniających pokrywają największą część badanego obszaru, bo aż $63 \%$.

3. Stawy rybne stanowią barierę dla zanieczyszczeń, częściowo redukując stężenia niektórych wskaźników. Poniżej zrzutu wody ze stawów w stosunku do wód zasilających odnotowano istotną redukcję stężeń azotu ogólnego o 66\%, amoniaku o $52 \%$, siarczanów(VI) o $50 \%$, azotanów(V) o $46 \%$ i fosforanów(V) o $28 \%$.

4. Dynamika transportu biogenów w systemie stawów rybnych cechuje się wyraźnym zróżnicowaniem sezonowym. Porównanie ładunków azotu i fosforu przepływających przez stawy w roku hydrologicznym 2015 w półroczu letnim i zimowym wskazuje, że zróżnicowanie sezonowe odzwierciedla odmienne warunki hydrologiczne w półroczach. W okresie zimowym do stawów wpływa znacznie większa pula ładunków wprowadzanych i wyprowadzanych w ciągu całego roku hydrologicznego.

5. Najwyższe ładunki azotu ogólnego wpływające i wydostające się z gospodarstwa przypadają na okres zimowy i początek jesieni, co spowodowane jest nawożeniem pól uprawnych lub brakiem rozwoju roślin w okresie zimy, a także zrzutem wody ze stawów.

6. Istnieje silna zależność między ładunkiem azotu ogólnego a odpływem w ciągu całego roku hydrologicznego, jak i w okresach półrocznych. Zanotowane maksima przepływów pokrywają się z maksymalnymi ładunkami wprowadzanymi do gospodarstwa. 


\section{Literatura}

Barszczewski J., Kaca E., Wojda R., 2010, Warunki srodowiskowe i wyniki produkcyjne we ekologicznym oraz konwencjonalnym chowie karpi, Journal of Research and Applications in Agricultural Engineering, 55 (3), 14-19.

Berleć K., Budzińska K., Pasela R., Stachowski P., 2015, Hodowla stawowa karpia i jej wptyw na stan mikologiczny wód powierzchniowych, Inżynieria Ekologiczna, 45, 135-139.

Bieniarz K., Kownacki A., Epler P., 2003, Biologia stawów rybnych, część I, IRS Olsztyn, Olsztyn.

Bogdał A., Ostrowski K., 2007, Wpływ rolniczego u:ytkowania zlewni Podgórskiej i opadów atmosferycznych na jakość wód odptywajqcych z jej obszaru, Woda-Środowisko-Obszary Wiejskie, 7 (2A), 59-69.

Bogdanowicz R., 2004, Hydrologične uwarunkowania transportu wybranych zwiq̨ków aะotu i fosforu Odrq i Wistq oraะ rzekami Przymorza do Battyku, Wyd. UG, Gdańsk.

Bonisławska M., Nędzarek A., Rybczyk A., Czerniejewski P., Żuk B., 2017, Zmiany warunków abiotycznych matej ræeki z uwzględnieniem wptywu wód poprodukcyjnych \& hodowli ryb, WodaŚrodowisko-Obszary Wiejskie, 17 (4), 5-23.

Bonisławska M., Nędzarek A., Rybczyk A., Żuk B., Tórz A., Socha M., Tański A., Gronowski S., Pender R., 2016, Wptyw hodowli materiatu sarybieniowego na jakośc wody poprodukcyjnej odprowadzanej do środowiska, Inżynieria Ekologiczna, 49, 143-150.

Bonisławska M., Tański A., Mokrzycka M., Brysiewicz A., Nędzarek A., Tórz A., 2013, The effect of effluents from rainbow trout ponds on water quality in the Gowienica River, Journal Water of Land Development, 19, 3-11.

Boyd C.E., 2003, Guidelines for aquaculture effluent management at the farm-level, Aquaculture, $226(1-4), 101-112$.

Dojlido R., 1995, Chemia wód powierzchniowych, Wyd. Ekonomia i Środowisko, Białystok.

Drabiński A., 1991, Wptyw gospodarowania wodq w stawach rybnych na odpływ se slewni rzeki Baryczy na przekroju Łqki, Zeszyty Naukowe Akademii Rolniczej we Wrocławiu, Rozpr. Hab., 90, Wrocław.

Ilnicki P., 2002, Przyczyny, \&ródta i przebieg eutrofiæacji wód powierzchniowych, Przegląd Komunalny, 2, 35-49.

Jawecki B., Kowalczyk T., Malczewska B., 2008, Wpływ temperatury powietræa na natlenienie strefy eufotycznej stawu karpiowego, Infrastruktura i Ekologia Terenów Wiejskich, 9, 195-206.

Kanownik W., Wiśnios M., 2015, Wpływ chowu karpia na stan fizykochemičny wody stawu i odbiornika, Inżynieria Ekologiczna, 44, 131-138.

Karoń K., 2011, Stawy rybne to nie tylko chów i hodowla ryb!, Kultura Wsi, http://www.zpryb.pl/ LinkClick.aspx?fileticket=CA7xldlH9aU\%3D\&tabid=1181 (dostęp: 12.05.2019)

Kelles-Krauz D., 2016, Instrukcja gospodarowania wodq w obiekcie stawowym Markowo-Podony (maszynopis). 
Kolasa-Jamińska B., 2004, Jakość wody spuszczanej ze stawów a termin odtowu ryb, Komunikaty Rybackie, 5, 10-12.

Kondracki J., 2012, Geografia regionalna Polski, PWN, Warszawa.

Koniecka H., Gębka W., 2015, Ocena jakości jednolitych cæęści wód powierzchniowych rzek badanych w 2014 roku, Wojewódzki Inspektorat Ochrony Środowiska w Olsztynie, delegatura w Elblągu, Elbląg (maszynopis).

Kosturkiewicz A., Muratowa S., Myszka A., 1993, Wptyw stawów rybnych na jakośćwód, Zeszyty Naukowe Akademii Rolniczej we Wrocławiu, 244, 51-63.

Michalczyk T., Bar-Michalczyk D., Zięba D., 2017, Wptyw naturalnych i sжtucznych spiętrzeń wody na redukcję stężen azotu w ciekach powierzchniowych na przyktadzie zlewni Kocinki (Wyżyna Wieluńska), Przegląd Geologiczny, 65 (11/2), 1339-1343.

Pawlik-Dobrowolski, J., Łempicka, A., 2003, Znaczenie mokrego i suchego opadu zanieczyszczeń w eutrofizacji wód w stawach na przyktadzie rezerwatu „Stawy Raszyńskie”, Woda-Środowisko-Obszary Wiejskie, 3 (6), 167-177.

Piętka I., 2009, Wieloletnia smienność wiosennego odptywu rzek polskich, Prace i Studia Geograficzne, 43, 81-95.

Popek Z., Wasilewicz M., Bańkowska A., Boczoń A., 2014, Sezonowa zmienność odphywu wody i ładunków biogenów ze zlewni Wielkiej Strugi do jeziora Zdworskiego, Monografie Komitetu Gospodarki Wodnej PAN, 20 (2), 341-354.

Pytka A., Jóźwiakowski K., Marzec M., Gizińska M., Sosnowska B., 2013, Ocena wpływu zanieczyszczen antropogenicznych na jakość wód rzeki Bochotniczanki, Infrastruktura i Ekologia Terenów Wiejskich, 3 (2), 15-29.

Quant, B., Haustein, E., Remiszewska-Skwarek, A., 2009, Ocena potencjalnego wptywu hodowli ryb tososiowatych na jakośí wód powierzchniowych, Gospodarka Wodna, 5, 202-205.

Radtke G., Bernaś R., Dębowski P., Skóra M., 2011, Ichtiofauna doræecæa ræeki Elblag, Roczniki Naukowe PZW, 24, 97-114.

Read P., Fernandes T., 2003, Management of environmental impacts of marine aquaculture in Europe, Aquaculture, 226, 139-163.

Rosporzqdzenie Ministra Środowiska w sprawie sposobu klasyfikacji stanu jednolitych częsci wód powier:chniowych oraw środowiskowych norm jakości dla substancji priorytetowych, Dz. U. poz. 1187 z dnia 5 sierpnia 2016 r.

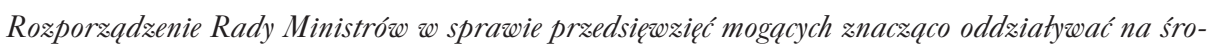
dowisko, Dz. U. 2016 poz. $71 \mathrm{z}$ dnia 9 listopada $2010 \mathrm{r}$.

Russell M.A., Walling D.E., Webb B.W., Bearne R., 1998, The composition of nutrient fluxes from contrasting UK river basins, Hydrological Processes, 12, 1461-1482.

Sidoruk M., Koc J., Szarek J., Skibniewska K., Guziur J., Zakrzewski J., 2013, Wptyw produkcji pstraga w stawach betonowych \& kaskadowym præeptywem wody na wtaściwości fizyczne i chemiczne wód powierzchniowych, Inżynieria Ekologiczna, 34, 206-213.

Wojda R., Zygmunt G., 2012, Wptyw stawów karpiowych na jakość, retencję i bilans wodny zlewni Komunikaty Rybackie, 3 (128), 1-3. 


\section{Strony internetowe}

http://geoserwis.gdos.gov.pl/mapy/ (dostęp: 06.07.2017).

http://mapy.geoportal.gov.pl/imap/ (dostęp: 06.07.2017).

Roman Cieśliński

Uniwersytet Gdański

Wydziat Oceanografii i Geografii

Instytut Geografii, Katedra Hydrologii

ul. Ba:̇ýnskiego 4, 80-952 Gdańsk

georc@univ.gda.pl

\section{Isabela Chlost}

Uniwersytet Gdański

Wydziat Oceanografii i Geografii

Instytut Geografii, Katedra Hydrologii

ul. Bażyńskiego 4, 80-952 Gdañsk

izachlost@op.pl

Karol Lewowicki

Uniwersytet Gdański

Wydziat Oceanografii i Geografii

Instytut Geografii, Katedra Hydrologii

ul. Ba:̇nńskiego 4, 80-952 Gdańsk

karol.lewowicki@o2.pl 